\title{
Prevalence of Burnout Syndrome in Physical Education teachers
}

https://doi.org/10.11606/issn.1981-4690.v35i3p9-15

\section{Abstract}

The objective was to verify the prevalence of Burnout Syndrome (BS) in Physical Education teachers from state schools in the metropolitan region of Belo Horizonte/MG. This is a cross-sectional study with a quantitative approach, its sample consisted of 47 teachers, being active in schools in the urban area, having at least 1 year of teaching in their current school. For data collection we used two instruments: a sociodemographic and labor questionnaire and the "Spanish Burnout Inventory", educational version (SBI-Ed). After analyzing the studies, it is clear that this was the first time that $\mathrm{SBI}$ was used in this professional class in Brazil. The results showed that the Physical Education teachers of the sample had Burnout, being $12.77 \%$ with the BS Profile 1 and $6.38 \%$ having the Profile 2. As initial results obtained from this sample demonstrates the need for longitudinal and epidemiological studies on this thematic, with a larger number of participants, to understand the possible consequences of people who have BS over the years; seen as a syndrome with several stages and processes for its prevalence.

KEYWORDS: Noncommunicable Diseases; School; CESQT; SBI.

\section{Introduction}

The study of the international literature indicates that there is no single definition of Burnout, but it is consensus until the studies developed today that it would be a response to chronic work stress, but should not be confused with stress. The Burnout Syndrome (BS) involves negative attitudes and behaviors concerning to users, clients, organization and work; it is a subjective experience, involving attitudes and feelings that bring practical and emotional problems to the worker and the organization. The concept of stress, on the other hand, does not involve such attitudes and behaviors, it is a personal exhaustion with interference in the individual's life and not necessarily in their relationship with work ${ }^{1}$.

Therefore, the syndrome is a pathology related to the great physical and emotional exhaustion directed to the excess of work activities, in which the exhaustion will not only reflect in work activities, but also in the family and social environment. A key aspect of the syndrome is increased feelings of emotional exhaustion. Another aspect is the development of negative attitudes and feelings, in addition to psychic exhaustion ${ }^{2,3}$.

Regarding the scientific production of $\mathrm{BS}$ in teachers, there are in the databases several studies in this area in many countries of the world ${ }^{4,5}$. This growing demand arises from the fact that it is a profession, that contact with stressors can be very large, and cause various types of absence from work. When referring to the literature, it is clear that the studies mainly use the Maslach Burnout Inventory (MBI) as a research instrument. In addition, research on BS with Physical Education (PE) professionals is relatively small, both with the MBI and with the instrument of the present study (SBI) ${ }^{4-6}$.

In the study by GuEDEs et al. ${ }^{7}$ composed of 588
*Minas Gerais State Secretary of Education, Belo Horizonte, MG, Brazil.

**Federal University of Minas Gerais, Belo Horizonte, MG, Brazil. 
subjects, when performing the analysis of the presence of Burnout in physical education teachers, it was observed that about $10.2 \%$ of the sample has the syndrome. In REyEs-OyOLA et al. ${ }^{8}$ with 111 PE teachers, aged 26 to 65 years, found about $19.8 \%$ of teachers with prevalence of the syndrome. However, in the research by TiErA et al. ${ }^{9}$ with 35 physical education professionals, no BS was identified in any sample, only the instrument subscales were identified in some participants. Thus, it is clear that there are factors that may interfere with the presence of this syndrome, for example the place where the study was performed and how it was designed.

Thus, was developed a theoretical and instrument model, the Spanish Burnout Inventory (SBI) to have an alternative evaluation, as the instrument most used worldwide (MBI) when it is adapted to other languages (excluding English), acquires insufficient psychometric frequency ${ }^{10,11}$.

This new instrument is formed by four dimensions: (1) Enthusiasm toward the job, defined as the individual's expectation to achieve certain workgoals, as this supposes a source of personal and professional achievement; (2) Psychological exhaustion, defined as the presence of emotional and physical exhaustion resulting from work activity, considering the need to relate daily with people who have or generate problems; (3) Indolence, defined as the presence of negative attitudes of indifference and cynicism towards the clients of the organization; (4) Guilt, defined as the occurrence of feelings of guilt for behavior and negative attitudes developed at work, especially in relation to people with whom the worker should relate professionally ${ }^{11}$.

The Burnout in teachers does not appear abruptly, but constitutes the final phase of a continuous process that has been going on. The lack of preparation of teachers puts them in a situation of emotional helplessness, contributing to the aggravation of symptoms of chronic stress $^{12,13}$. The professionals PE, because of the profession peculiarities, may perhaps be part of a category of most vulnerable professionals to work stress because they have very close and intensive contact with the recipients of their services and face physical and emotional stressful situations during their tasks. Thereby, they may become tired teachers, disillusioned with the profession, without the desire to teach, implying a low level of teaching quality ${ }^{7,14}$.

The causes and consequences of this syndrome in Physical Education teachers refer to: relational aspects (interpersonal relationships at work); excessive workload; lack of professional appreciation; classes with too many students; lack of technical support; violence against the teacher and students' social reality; multiplicity of non-area specific functions and poor working conditions (lack of physical structure and teaching materials) ${ }^{15-17}$.

Analyzing these causes of BS, one realizes that it is a set of factors that may influence the onset of this syndrome, and that it does not appear quickly, but after the teacher is totally worn out. Not only within the classroom is there a stress disorder for the teacher, the relationship with parents and labor lawsuits also affect him providing greater stress.

Thus, the need to study BS is linked to the need to study stress processes at work, as well as the emphasis that organizations have been placing on the need to worry more about the quality of work life they offer to their employees officials ${ }^{18}$. Thus, the study proposes to verify the prevalence of Burnout Syndrome in Physical Education teachers in state schools in the metropolitan region of Belo Horizonte/MG.

\section{Methods}

This is a cross-sectional study with a quantitative approach, which consisted of Physical Education teachers of both sexes, from the public schools of the metropolitan region of Belo Horizonte/MG.

\section{Collection and ethical procedures}

Data collection occurred after approval by the University Research Ethics Committee, with case number CAAE 93913318.2.00o0.5153. In addition, the authorization of the Minas Gerais State Secretary of Education (SEE/MG) to obtain the study in the contemplating schools was obtained.

After the authorizations, calls were made to all research schools to verify that the information provided by the Secretariat was reliable. The research participants were approached by the researcher in their work environment, who invited them to participate in the research, explaining all relevant information of the study, and handed in the Informed Consent Form (ICF) and the questionnaires. If the teacher was not available at the time of collection, the instruments were left at the office to be collected seven days later. 


\section{Participants}

Thirty schools participated in this research, 66 Physical Education teachers were invited to participate in this research, obtaining 47 (71.21\%) participants, belonging to the state network of the metropolitan region of Belo Horizonte, from the cities: Betim; Esmeraldas; Florestal; Juatuba and Mateus Leme. The sample included 24 men and 23 women, with a average age of 38.23 years $(\mathrm{SD}=$ 6.85 ), with a range of 28 to 58 years. Teachers have a stable marital relationship (57.4\%), with higher education, most of the sample (48.9\%) considering brown, and the largest number of teachers in the salary range $(46.8 \%)$ from 3 to 4 minimum wages.

The average time of practice of the profession was 12.48 years $(\mathrm{SD}=6.06)$, and the average of professional practice in the current educational institution of 6.39 years $(\mathrm{SD}=$ 4.76). The weekly workload averaged 31.70 hours (SD = 13.72), and most teachers are exclusively dedicated to a single school (61.7\%). They serve an average of 34 students per class $(\mathrm{SD}=6.25)$ and work in more than one shift (26 teachers - 55.3\%).

Effective Physical Education teachers from the state who worked in schools in the urban area of the metropolitan area of Belo Horizonte, who were in the classroom and with more than one year of teaching activity at their current institution were considered for this study. Physical education teachers working in state schools in the rural area of the metropolitan region of Belo Horizonte and those who only perform administrative activities were excluded from the research.

\section{Instruments}

Participants responded to two instruments. The first was a Sociodemographic and Labor Data Questionnaire, which was prepared by the researchers based on the literature ${ }^{16,19}$, seeking to collect data regarding the teacher, such as: age, gender, marital status, title and family income; and also information about your work, such as length of profession, work shift, weekly workload and average student per classroom. Subsequently, to evaluate the Burnout Syndrome, we used the "Spanish Burnout Inventory", Education professionals version (SBI-Ed), which is an instrument of data collection that identifies syndrome factors ${ }^{11}$.

The instrument consists of twenty items, which are divided into four subscales, called: Enthusiasm toward the job (EJ) with five items; Psychological exhaustion (PE) with four items; Indolence (I) with six items; and Guilt (G) with five items. Items are rated on a five-point frequency Likert - type scale, with o for "never", 1 for "rarely: sometimes a year", 2 for "sometimes: sometimes a month", 3 for "often: a few times a week" and 4 to " very often: every day". From this model result two profiles, profile 1 characterized by low enthusiasm toward the job and high psychological exhaustion and indolence. Profile 2 defines the presence of the dimensions described in Profile 1, plus the increased feeling of guilt ${ }^{11}$.

\section{The statistical analysis}

For data analysis Descriptive statistics were used to test and first internal consistency of SBI calculated the coefficient a Cronbach , the four dimensions instrument: Enthusiasm toward the job (alpha= 0.90); Psychological exhaustion (alpha= 0.80); Indolence (alpha= 0.72); and, Guilt (alpha $=0.80$ ), presenting moderate to high internal consistency according to the reliability classification where they assume that higher alpha values may indicate even better degrees of reliability ${ }^{20}$.

Prior to the tests, the normality analysis was performed by the Kolmogorov-Smirnov test, and the results indicated the non-normality of the data $(\mathrm{p}<0.05)$.

\section{Results}

The Cronbach alpha values in this study showed that the averages were highest in the dimension illusion study (TABLE 1), high scores which indicate low levels of Burnout Syndrome. All subscales had values above 0.70: Enthusiasm toward the job, alpha $=0.90 ;$ Psychological exhaustion, alpha $=0.80$; Indolence, alpha $=0.72 ;$ and Guilt, alpha $=0.80$ (TABLE 1). The average dimension, the highest value obtained was for the Enthusiasm toward the job
$(\mathrm{M}=3.05 ; \mathrm{SD}=1.01)$, whose variables are analyzed differently from SBI, they are formulated in a positive sense (high scores are indicative of low levels of the syndrome). The dimension with the lowest value was Indolence $(\mathrm{M}=1.01 ; \mathrm{SD}=0.97)$.

Most of the results found were between the medium to high levels in relation to the calculation of percentiles (P10, P33, P66 and P9o). In addition to these cases, attention should also be paid to cases that demonstrated 
very low levels of Enthusiasm toward the job (12.77\%), and critical levels of Psychological exhaustion (17.02\%), Indolence (8.51\%) and of Guilt (6.38\%).

After converting the scores into percentiles, the Burnout profile was identified. The Profile 1 consisted of the average of the 15 items of the subscales Enthusiasm toward the job (inverted subscale), Psychological exhaustion and Indolence; and Profile 2 was elaborated by adding the average dimension Guilt $^{21}$. The results regarding the prevalence of
Burnout Syndrome, in this sample of teachers from state schools in the metropolitan region of Belo Horizonte, indicated that $12.77 \%(n=6)$ of the evaluated ones had BS Profile 1, and 6.38\% $(\mathrm{n}=3)$ Profile 2 (TABLE 2). Even with the results showing a relatively low number of teachers, some concern should be taken, as they are high for the dimensions of Guilt, Indolence and low for Enthusiasm toward the job, as they are characteristics for later possible incidence of Profile 1.

TABLE 1 - Mean, Standard Deviation and Internal Consistency (Cronbach's alpha) of SBI-Ed dimensions.

\begin{tabular}{lccc}
\hline Variables & $\mathbf{M}$ & SD & $\boldsymbol{\alpha}$ \\
\hline Enthusiasm toward the job & 3.05 & 1.01 & 0.90 \\
Psychological exhaustion & 1.58 & 1.18 & 0.80 \\
Indolence & 1.01 & 0.97 & 0.72 \\
Guilt & 1.03 & 1.07 & 0.80 \\
\hline
\end{tabular}

TABLE 2 - Profile 1 and Profile 2 with high and low Burnout levels.

\begin{tabular}{ccc}
\hline & High Levels ( $\geq \mathbf{2})$ & Low Levels (<2) \\
\hline SBI-Ed (Profile 1) & $6(12.77 \%)$ & $41(87.23 \%)$ \\
SBI-Ed (Profile 2) & $3(6.38 \%)$ & $44(93.62 \%)$ \\
\hline
\end{tabular}

\section{Discussion}

This study conducted with the Physical Education teachers of the state and metropolitan region of Belo Horizonte had results in both profiles of the syndrome (12.77\% in Profile 1 and $6.38 \%$ in Profile 2), similar to the results of a study with 714 teachers from the metropolitan region of Porto Alegre (RS), where participants had $12.0 \%$ high BS levels (Profile 1) and $5.6 \%$ had Profile $2^{22}$. A survey of 169 higher education teachers from Piracicaba (SP) also had similar values to those obtained in the present study, Profile $1=11.2 \%$ and Profile $2=3 \%^{23}$.

In an investigation conducted with Colombian physical education teachers, the overall result found in the sample was $13.5 \%$ for Profile 1 and $6.3 \%$ for Profile 2. Thus, the results obtained in this research corroborate $^{8}$. Still, it was observed in 211 Portuguese teachers, a prevalence of $14.2 \%$ of Profile 1 and $1.9 \%$ of Profile $2^{24}$.

However, when compared with other research with teachers, some divergent results are found with the present results. An investigation of 698 Mexican faculty members found Burnout prevalence in $35.50 \%$ for Profile 1 and $\mathbf{1 7 . 2 0 \%}$ for Profile $2^{25}$; As well as another survey of 88 special education 
teachers, there was a prevalence of $3.4 \%$ of the sample with Profile 1 and Profile 2 of $\mathrm{BS}^{26}$. An investigation was also conducted with 35 physical education professionals in which no one was found with the syndrome ${ }^{9}$. These divergences are possibly due to the specificities of the places where participants were surveyed.

Regarding the variables of the instrument used in this study, we obtained in Enthusiasm toward the job $(\mathrm{M}=3.05 ; \mathrm{SD}=1.01)$, Psychological exhaustion $(\mathrm{M}=1.58 ; \mathrm{SD}=1.18)$, in the Indolence dimension $(\mathrm{M}=1.01 ; \mathrm{SD}=0.97)$ and Guilt $(\mathrm{M}=1.03 ; \mathrm{SD}=1.07)$. In the study by CARLOTTO et al. ${ }^{27}$ gave similar results for these dimensions: $\mathrm{EJ}(\mathrm{F}=3.40 ; \mathrm{SD}=0.66) ; \mathrm{PE}$ $(\mathrm{M}=1.36 ; \mathrm{SD}=0.85) ; \mathrm{I}(\mathrm{M}=0.54 ; \mathrm{SD}=0.44) ; \mathrm{G}$ $(M=1.10 ; S D=0.63)$. Similarly, in a survey of 80 regular teachers, similar results were obtained for the dimensions of this EJ survey $(\mathrm{M}=2.96 ; \mathrm{SD}=$ 0.80); $\mathrm{PE}(\mathrm{M}=1.59 ; \mathrm{SD}=0.99) ; \mathrm{I}(\mathrm{M}=0.97 ; \mathrm{SD}=$ 0.80); $\mathrm{G}(\mathrm{M}=1.09 ; \mathrm{SD}=0.76)^{28}$.

Thus, it is clear that the sample of the present study has cases with Burnout Syndrome, both in its less severe form (where the teacher can work, but not totally motivated) and in the more severe one (with signs of guilt). However, it should be noted that in the rest of the sample there were results with individuals with high values in Guilt, Indolence and low in Enthusiasm toward the job.

In a study related to teaching and its illness, it was found that the possible causes of psychopathology are multiple and complex and consider the following factors that may influence these indices: the challenges of the formation and exercise of the profession, the demands of the educational system and the parents of students, the insecurity and violence of working with socially vulnerable publics, financial insecurity, the devaluation of the profession, and events involving affective relationships, whether family or otherwise ${ }^{29}$.

Therefore, the manifestation of symptoms of this syndrome occurs in people who did not previously suffer from any psychopathological disorder. Still, as a result of the symptoms of mental and emotional exhaustion, the increasing severity of fatigue and depression, there is a notable decline in the development of work activities, which can ultimately compromise and end the teacher's professional activity. Thus, it should be highlighted some possible causes of this syndrome and seek alternative prevention and treatment for it 9 .

Since 2001, the Manual of Procedures for Health Services, launched by the Pan American Health Organization in Brazil ${ }^{30}$ reported that the treatment of occupational Burnout Syndrome involves psychotherapy, pharmacological treatment and psychosocial interventions. However, the intensity of the prescription of each therapeutic resource depends on the severity and specificity of each case. In 2019, the Brazilian Ministry of Health ${ }^{31}$, after the World Health Organization reported that it will include the syndrome in the new International Classification of Diseases, stressed in addition to the treatment mentioned above, that the patient being treated (between one and three months) perform regular physical activity and relaxation exercises.

Thus, to specify each case and its severity, research in the area is needed to demonstrate the various facets of this syndrome. In view of these results, in which Burnout Syndrome is perceived in a portion of the sample, longitudinal studies should be produced to identify the possible causes and consequences of BS over the years.

The prevalence of Burnout Syndrome that was found in the sample is relatively low, however, several teachers had a high rate of Burnout development. Moreover, an important factor that must be considered is that the development process of this syndrome is not instantaneous but gradual. Thus, the physical education teacher is a professional who is continuously in contact with people, being a profession that can cause stress and Burnout over the years and even lead to the development of Burnout. This syndrome is present today in large scale, in most cases there is no understanding of the population about it, as there may be confusion in the diagnosis, and BS can be confused with stress or depression.

The syndrome is a much more complex and expensive process, being closely related to the health of the individual in the organizational environment. Other studies are of fundamental importance with a larger sample, with more information on the subject, as well as epidemiological researches, to make the appropriate analyzes in order to promote better quality of life for patients with BS. 


\section{Resumo}

Prevalência da Síndrome de Burnout em Professores de Educação Física.

O objetivo foi verificar a prevalência da Síndrome de Burnout (SB) em professores de Educação Física, das escolas estaduais da região metropolitana de Belo Horizonte/MG. Trata-se de um estudo transversal com abordagem quantitativa, onde a sua amostra foi composta por 47 professores, sendo atuantes em escolas da zona urbana, possuindo no mínimo 1 ano de docência na sua atual escola. Para coleta de dados foram utilizados dois instrumentos: um questionário sociodemográfico e laboral e o "Cuestionário de la Evaluación del Síndrome de Quemarse por el Trabajo" (CESQT). Após análises dos estudos, percebe-se que foi a primeira vez que se utilizou o CESQT nesta classe profissional no Brasil. Os resultados demonstraram que os professores de Educação Física da amostra apresentaram Burnout, sendo $12,77 \%$ com o Perfil 1 da SB e 6,38\% possuindo o Perfil 2. Os resultados iniciais obtidos diante desta amostragem demonstram a necessidade de estudos longitudinais e epidemiológicos sobre esta temática, com um número maior de participantes, para o entendimento a respeito das possíveis consequências, das pessoas que possuem a SB no decorrer dos anos; visto ser uma síndrome com diversas etapas e processos para a sua prevalência.

Palavras-chave: Doenças Não-transmissíveis; Escola; CESQT; SBI.

\section{References}

1. Codo W, Vasques-Menezes I. O que é Burnout? In: Codo, coordenador. Educação: carinho e trabalho. 4. ed. Petrópolis: Vozes, 2006. Cap. 13, p. 237-254.

2. Mota GS, Alencar CMS, Tapety FI. Síndrome de Burnout em profissionais de saúde: uma revisão bibliográfica da literatura. Rev Eletrônica Acervo Saúde. 2017;(5 supl):237-241.

3. Maslach C, Jackson SE. The measurement of experienced burnout. J Occup Behaviour. 1981;2:99-113.

4. Küçüksüleymanoğlu R. Burnout syndrome levels of teachers in special education schools in Turkey. Int J Special Educ. 2011;26(1):53-63.

5. Platsidou M. Trait Emotional intelligence of greek special education teachers in relation to Burnout and job satisfaction. School Psychol Int. 2010;31(1):60-76.

6. Bataineh O. Sources of social support among special education teachers in Jordan and their relationship to Burnout. Int Educ. 2009;39(1):65-78.

7. Guedes D, Gaspar E. "Burnout” em uma amostra de profissionais de Educação Física brasileiros. Rev Bras Educ Fís Esporte. 2016;30(4):999-1010.

8. Reyes-Oyola FA, Palomino-Devia C, Aponte-López NW. Síndrome de quemarse por el trabajo, índice de masa corporal y otros factores asociados a la labor de los profesores de educación física colombianos. Biomédica. 2019; 39(3):1-29.

9. Tiera VL, Ulbricht L, Ripka WL. A prevalência da síndrome de burnout nos profissionais de Educação Física. Lecturas Educ Fís Deportes Rev Digital. 2011;16(163).

10. França SPS, Martino MMF, Vasconcelos EM, Silva LL. Diferentes metodologias e ferramentas de avaliação em saúde da Síndrome de Burnout. Rev Enferm UFPE On line. 2016;10(8):3069-76.

11. Gil-Monte PR, Carlotto MS, Câmara SG. Validação da versão brasileira do "Cuestionario para la Evaluación del Síndrome de Quemarse por el Trabajo” em professores. Rev Saúde Pública. 2010;44(1):140-7.

12. Haase VG, Júlio-Costa A, Silva JBL. Por que o construtivismo não funciona? Evolução, processamento de informação e aprendizagem escolar. Psicol Pesquisa. 2015;9(1):62-71.

13. Moreno-Jimenez B, Garrosa-Hernandez E, Gálvez M, González JL, Benevides-Pereira AMT. Avaliação do burnout em professores. Comparação de instrumentos: cbp-r e mbi-ed. Psicol Estudo. 2002;7(1):11-19.

14. Santini J, Molina Neto V. A síndrome do esgotamento profissional em professores de educação física: um estudo na rede municipal de ensino de Porto Alegre. Rev Bras Educ Fís Esporte. 2005;19(3):209-22.

14 • Rev Bras Educ Fís Esporte, (São Paulo) 2021 Jul-Set;35(3):9-15 
15. Vidal ERS. Síndrome burnout em professores. Pedagogia em Ação. 2017;9(1):39-46.

16. Silva GMS. Síndrome de Burnout em professores de Educação Física da Rede Pública Estadual de Sergipe. Dissertação (Mestrado em Educação Física) - Universidade Federal de Sergipe. São Cristóvão p. 68. 2014.

17. Leite MP, Souza AN. Condições de trabalho e suas repercussões na saúde dos professores da educação básica no Brasil. Educ Soc. 2011;32(117):1105-1121.

18. Gil-Monte PR. El Síndrome de Quemarse por el Trabajo en Enfermería. Rev Eletrônica InterAção Psy. 2003;1(1):19-33.

19. Sinott, EC. Síndrome de Burnout: um estudo com professores de Educação Física das escolas municipais de Pelotas - RS.

Dissertação (Mestrado em Educação Física) - Universidade Federal de Pelotas. Pelotas, p. 134. 2013.

20. Freitas ALP, Rodrigues SG. A avaliação da confiabilidade de questionários: uma análise utilizando o coeficiente alfa de Cronbach. In: XII SIMPEP - Bauru, SP, Brasil, 2005. Anais... Bauru, SP, Brasil, 7 a 9 de Novembro de 2005.

21. Gil-Monte PR. CESQT. Cuestionario para la evaluación del Síndrome de Quemarse por el Trabajo. Manual. Madrid: TEA, 2011. 22. Gil-Monte PR, Carlotto MS, Câmara SG. Prevalence of burnout in a sample of Brazilian teachers. Eur J Psychiat. 2011;25(4):205-212.

23. Costa LST, Gil-Monte PR, Possobon RF, Ambrosano GMB. Prevalência da Síndrome de Burnout em uma amostra de professores universitários brasileiros. Psicol Reflexão Crítica. 2013;26(4):636-642.

24. Figueiredo-Ferraz H, Gil-Monte PR, Grau-Alberola E. Prevalencia del Síndrome de Quemarse por el Trabajo (Burnout) en una muestra de maestros portugueses. Aletheia. 2009;29:6-15.

25. Rojas SU. Estudio de prevalencia del Síndrome de Quemarse por el Trabajo (SQT) y su asociación con sobrecarga y autoeficacia en maestros de primaria de la Ciudad de México. Cienc Trabajo. 2010;12(35):257- 262.

26. Braun AC, Carlotto MS. Síndrome de burnout em professores de ensino especial. Barbarói. 2013;39:53-69.

27. Carlotto MS, Librelotto R, Pizzinato A, Barcinski M. Prevalência e factores associados à Síndrome de Burnout nos professores de ensino especial. Análise Psicol. (2012);30(3):315-327.

28. Braun AC, Carlotto MS. Síndrome de Burnout: estudo comparativo entre professores do Ensino Especial e do Ensino Regular. Rev Quadrimestral Assoc Bras Psicol Escolar e Educacional. 2014;18(1):125-133.

29. Ischiara JC, Neto ARL, Teixeira IF, Santos MC, Neto MAR. Docência e adoecimento: uma investigação para um tema (re) descoberto. Rev Expressão Católica. 2015;4(2):32-39.

30. Ministério da Saúde do Brasil. Organização Pan-Americana da Saúde no Brasil. Doenças relacionadas ao trabalho: manual de procedimentos para os serviços de saúde. Organizado por Elizabeth Costa Dias; colaboradores Idelberto Muniz Almeida et al. Brasília, 2001.

31. Ministério da Saúde. Síndrome de Burnout: o que é, quais as causas, sintomas e como tratar. [internet]. Disponível em: <http://www.saude.gov.br/saude-de-a-z/saude-mental/sindrome-de-burnout>. Acesso em: 14 set. 2019.

\begin{tabular}{r|r} 
ADDREss & \\
Bruno Macedo Souza & \\
Rua Sergipe, 631 - Santo Afonso & Submitted: 07/28/2020 \\
32623-622 - Betim - MG - Brasil & Accepted: 01/04/2022 \\
E-mails: brunomcsouza@gmail.com & \\
bruno.macedo.souza@educacao.mg.gov.br &
\end{tabular}

